\title{
Téma homosexuality v ukrajinské literatuře
}

\author{
Jaroslav Sommer (Hradec Králové)
}

\begin{abstract}
Abstrakt
Článek je zaměřen na současnou ukrajinskou literaturu a na to, jakým způsobem nakládá s tématem homosexuality. Toto téma je ukrajinskými spisovateli a básníky do literatury začleňováno od počátku devadesátých let. Od té doby prošlo mnohými metamorfózami, různí autoři k zobrazování homosexuality ve svých dílech přistupovali z různých hledisek. Pro Jurije Andruchovyče je na počátku devadesátých let homosexualita jedním z projevů rozpadajícího se totalitního režimu, Oksana Zabužko v ní nachází nový pohled do psychiky postavy a Oles Uljanenko zobrazuje homosexuální chování jako organickou součást svého obrazu světa. Spisovatelé pišící gay literaturu se ve své tvorbě zaměřují, podobně jako Uljanenko, na začlenění tématu mezi běžné náměty (Jurij Jarema), přestože jsou jejich možnosti omezené. Jiní autoři se snaží na tématu vystavět celou svou tvorbu (Vitalij Juchymenko), prípadně téma nejen zpracovávají, ale dodávají mu i poetiku typickou pro tvorbu cílenou na čtenáře náležejícího k sexuálním menšinám (Oles Barlih).
\end{abstract}

\section{Klíčová slova}

homosexualita; LGBT; ukrajinská literatura; gay literatura; Jurij Andruchovyč; Oksana Zabužko; Oles Uljanenko; Jurij Jarema; Vitalij Juchymenko; Oles Barlih

\section{Abstract \\ The Theme of Homosexuality in Ukrainian Literature}

The article is focused on contemporary Ukrainian literature and how it deals with the theme of homosexuality. This theme has been included by Ukrainian writers and poets into literature since the beginning of the 1990s. Ever since then it has undergone numerous metamorphosis, various authors have approached the theme of homosexuality in their works from a variety of viewpoints. For Yurii Andrukhovych homosexuality at the beginning of the 1990s one of the expressions of the crumbling totalitarian regime, for Oksana Zabuzhko it represents a new insight into the psyche of a person and Oles Ulianenko displays homosexual behaviour as an organic part of his view of the world. Writers who produce gay literature focus in their work, similarly to Ulianenko, on the inclusion of the topic into common themes (Yurii Yarema) even if their options are limited. Other authors try to build all of their works on this theme (Vitalii Yukhimenko), or they not only cover this theme, but they also infuse their work with poetics typical for works focused on readers that belong to some sexual minority (Oles Barlih).

\section{Key words}

homosexuality; LGBT; Ukrainian literature; gay literature; Yurii Andrukhovych; Oksana Zabuzhko; Oles Ulianenko; Yurii Yarema; Vitalii Yukhimenko; Oles Barlih 
Ukrajinská literatura v posledních desetiletích směřuje $\mathrm{k}$ rozvíjení postmoderny, často inspirované výdobytky různých nejen západoevropských literatur. Tento vývoj, samozřejmě značně propojený $\mathrm{s}$ rozsáhlými společenskými změnami souvisejícími s rozpadem SSSR, s sebou přinesl nejen nové pojetí už dříve rozvíjených témat, ale i trendy pro ukrajinskou literaturu nové. ${ }^{1}$ Často bývá v souvislosti s těmito změnami zmiňován termín „postkolonialismus“. Např́klad Tatiana Hofmann však (a je třeba poznamenat, že ojediněle) postmodernu i postkolonialismus zpochybňuje jako snahu přenést na Ukrajinu cizí měř́tka. ${ }^{2} \mathrm{~V}$ následujícím textu se zaměříme na to, jakým způsobem se v současné ukrajinské literatuře zabydluje téma homosexuality.

Při charakterizaci současné ukrajinské literární tvorby se Tereza Chlaňová přiklání k existenci dvou protichůdných vývojových tendencí, které nazývá „modernizace“ a „tradicionalismus" a jež mohou napomoci $\mathrm{k}$ vytvoření základního přehledu o představě autorů, kam by literatura měla dále směřovat. ${ }^{3}$ Protože naším cílem bylo zmapovat část literatury začleňující téma homosexuality do ukrajinské literatury, zaměřili jsme se na ty z autorů, kteří pod heslem „modernizace“ (chcete-li - „postmodernizace“) hledají inspiraci především na západ od ukrajinských hranic.

Literaturu, v níž se téma homosexuality objevuje, můžeme dělit dle nejrůznějších hledisek. Níže se nejprve budeme soustředit na texty, ve kterých je homosexualita pro spisovatele pouze vedlejším tématem. Následně se náš zájem přesune i $\mathrm{k}$ autorům, jejichž díla jsou primárně zaměřena právě na problematiku sexuálních menšin a na jejich př́slušníky.

Pro přehlednost jsme $\mathrm{z}$ celkového objemu vybrali ty autory, kteří jsou dostatečně úspěšní, aby „ovlivnili“ nejen ukrajinské čtenáře, ale i další spisovatele - a zároveň přinášejí něco nového, představují pro ukrajinskou literaturu originální pohled na téma homosexuality. Autoři píśící tzv. gay literaturu jsou jen ve výjimečných případech zaznamenáni širším čtenářským publikem.

K autorům známým a uznávaným i za hranicemi Ukrajiny patří Jurij Andruchovyč. Zajímavé narážky na homosexualitu nacházíme $\mathrm{v}$ jeho románu publikovaném v roce 1993 Moskoviáda (Московіада). V Andruchovyčově díle jsou zmínky o homosexualitě a homosexuálech jedním z projevů dokládajících postupný rozklad společnosti, předvoj dalších změn, k nimž se na konci osmdesátých a počátku devadesátých let schylovalo: „Проводжає тебе досить масним поглядом. Щось останнім часом забагато гоміків розвелося - чуютъ, певно, прийдешні зміни к законодавстві і все відвертіше виявляють свої оригінальні нахили.“"

1 MERZOVÁ, Radana: Současná ukrajinská literatura. In: PECHAL, Zdeněk a kol.: Současná ruská, polská a ukrajinská literatura. Olomouc: Univerzita Palackého v Olomouci, 2013, s. 283-285.

2 CHOFMAN, Tatjana: Literaturnyje etnografii Ukrainy: Proza posle 1991 goda. Sankt-Peterburg: Aletejja, 2016, s. 12.

3 CHLAŇOVÁ, Tereza a kol.: Putováni současnou ukrajinskou literárni krajinou. Prozaická tvorba představitelů tzv. „stanislauského fenoménu“. Červený Kostelec: Pavel Mervart, 2010, s. 51.

4 ANDRUCHOVYČ, Jurij: Moskoviada. Dostupné na: http://www.ukrcenter.com/Лiтература/Юрій-Андрухович/24810-6/ Московіада [cit. 27. 12. 2016, online] 
Později se v románu objeví přirovnání gayů a leseb k nekrofilům, narkomanům, ale také grafomanům a dealerům. Zároveň se tedy ukazuje, že homosexuálové jsou sice zařazeni do nepř́iliš sympatického kolektivu představujícího negativní jevy ve společnosti, avšak že na seznam může být připsán v podstatě každý: „... Стільки повсємєсно иих жидів, екстрасенсів розвелося, а ще наркоманів, гоміків, лесбіянок [...] Некрофілів, скотоложиів..

- Графоманів, - докинув ти.

- Рокерів, брокерів, ділерів, - булькнула кубанка.

- Порнографію на кожному кроиі продають, - не втримався Палкін. "

Andruchovyč pracuje s mnohými stereotypy, které se v souvislosti s homosexuály postupně vytvořily. Autor s takovými představami v románu pracuje jako s fakty, která, více než kdy dříve, mají vliv na funkčnost celé společnosti. Pocit agónie impéria tak nakonec nejúspěšněji navodí v okamžiku, kdy varuje před tím, že gayové se infiltrovali do armády, přičemž armáda tvořená homosexuály je nepoužitelná, nebot přišla o svou maskulinitu a s ní o vlastenecké přesvědčení bojovat za svůj stát: „Бути Великій Державі чи бути Великому Хаосу. Ієрархи чи анархї. Стрункості наших ідей вороги протиставили свист і гулюкання. Розвалюється фактично все. Трішать по швах святині і танки. Армія вже не здатна виконувати накази прашурів: вона симулює. Вона бридиться вбивати. Це вже не армія - це велике збіговисько педерастів і пачифістів, що, зрештою, одне й те ж. Мусимо визнати: у нас нині армї нема. Нема! Однак, чи випливає з иъого неминучість найбільшої

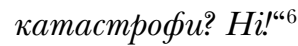

Oksana Zabužko, další z výrazných ukrajinských literátů, vešla do povědomí čtenářů, kritiků i literárních vědců především jako autorka románu Polni výzkum ukrajinského sexu. Pro nás je však zajímavější pozdější soubor autorčiných kratších próz z roku 2003 vydaný pod názvem Sestro, sestro (Сестро, сестро). V povídce Děvčátka (Дівчатка) se setkáváme s jiným př́istupem, než přinesl Andruchovyč, nebot Zabužko se snaží nahlížet homosexuální chování zevnitř a sleduje tak city a prožívání své hrdinky. Autorka nejen, že se zaměřuje na pro spisovatele méně atraktivní ženské téma, ale navíc ani nepíše o lesbách, ale spíše o lesbickém chování vyvolaném v dívkách v průběhu dospívání, o objevování sexuality: „...коли Ления, зиіловуючи вологі доріжки з Дарчиних шік, притислась губами до $\dddot{\imath}$ губ і на мить завмерла, задихнувшисъ, ї̈ серденъко гупало Дариі всередині, й обидві злякано заклякли, не знаючи, що робити далі ..."7

Autorka v povídce prolíná několik různých pohledů na lesbické chování dívek, nebot čistě dětské vidění jejich vztahu je kombinováno s dospělejším, zpětným hodnocením hrdinky, která díky tomu může porovnávat své první zkušenosti se sexualitou s pozdějšími vztahy s muži, což je celé ještě viděno z pozice té emocionálně angažovanější dívky ve vztahu: „Точніше, делалі більше сил ішло, принаймні в Дарки, на їі підтримання, бо всі їхні тремтямі припадання до себе, всі палкі поиілунки й рясніючі, по наростаючій, пестощі вибухали не самі собою, тобто не з чисто тілесного інтересу, як то потім було

5 ANDRUCHOVYČ, Jurij: Moskoviada. Dostupné na: http://www.ukrcenter.com/Лiтература/Юрій-Андрухович/24810-9/Московіада [cit. 27. 12. 2016, online]

6 ANDRUCHOVYČ, Jurij: Moskoviada. Dostupné na: http://www.ukrcenter.com/Лiтература/Юрій-Андрухович/24810-10/Московіада [cit. 27. 12. 2016, online]

7 ZABUŽKO, Oksana: Sestro, sestro. Kyjiv: Fakt, 2004, s. 46. 
з хлопиями, а, шоразу й незмінно, розв язкою якоӥнебудъ чергової емоиійної накрутки, такої собі невеличкої драми ..."8

Dalším autorem, jenž neváhal do svých děl začleňovat homosexuální postavy, byl Oles Uljanenko. Nejvýrazněji tak učinil v románu Жінка його мpï, do nějž umístil hned několik homosexuálních postav a který brzy po svém vydání proslul i díky cenzurním zásahům ospravedlňovaným bojem s pornografií. ${ }^{9}$ Uljanenko v roce 2007 napsal román Tady na Jihu (Там, де південь) а přenesl tím čtenáře do sedmdesátých let do svérázného prostředí ukrajinského Mykolajivu. Přestože se děj odehrává v době, kdy mužská homosexualita byla klasifikována jako trestný čin a objektivních informací o ní dostupných bylo poskrovnu, nezdá se, že by hrdinům románu připadala jako něco nevšedního. Autor $\mathrm{s}$ homosexuálními motivy naopak zachází jako s běžnou součástí městského koloritu: „Ми стирчали в барі “Садко» з дебілкуватими вітражами, офічіантками, що підпрачъовували у дяді Фіми, й двома офічіантами, що тоді просто називалися підарасами, а нині транссесксуалами." 10

Kriminálnímu prostředí, jež Uljanenko popisuje, dodávají na uvěřitelnosti a surovosti zmínky o homosexuálních praktikách prováděných „z nudy“, oproštěných od skutečné sexuality zúčastněných. Tento dojem Uljanenko ještě umocňuje tím, že to jsou předčasně dospělé děti ulice, kdo tímto způsobem tráví čas: „I Біба, завантажений рижухою, в повному ульоті, подався на Аляуди до мєлких, які вже припасали, шоб припєтушити, чергову жертву - звісно, зі свого оточення. Мєлкі, крім курива, ачетону, активної й пасивної підарастї не могли вигадати ніякої іншої розваги. Що може дати розніжений південний мармеладовий полуденъ?"11

Uljanenko o několik odstavců později narušuje klasický motiv typický pro soužití kriminálních živlů inspirovaný realitou ${ }^{12}$, kdy osoba přinucená k pasivní roli při homosexuálním styku, ztrácí své postavení ve společnosti. Vzhledem k tomu, jak je mezi některými románovými postavami homosexualita všední činností, není pak takové chování překvapivě důvodem k jakékoliv reakci: „Тому шо Спаба, запєтушений Пєиою, нині верховода усіх мєлких, - у них ие проходило просто, - не мав настрою слухати його баклани, тупі й незрозумілі баклани, тим паче на порожняк. Те, що його відтрахали мужики, нічого не означало. Дивись, вони гвалтують когось скопом, а потім він разом із ними гуляє, п'є. Ось така підарастична демократія." 13

Mezi autory, pro něž se homosexualita stává hlavním tématem jejich tvorby, je situace samozřejmě o něco odlišná, avšak přesto i zde nalézáme rozličné úhly pohledu. Existují

8 Tamtéž, s. 49.

9 STEPULA, Nadija: U znjatomu na plivku dni. Kyjiv: Ukrajins'kyj priorytet, 2012, s. 181-189.

10 ULJJANENKO, Oles': Tam, de pivden'. Dostupné na: http://www.rulit.me/books/tam-de-pivdenread-394749-6.html [cit. 27. 12. 2016, online]

11 ULJANENKO, Oles': Tam, de pivden'. Dostupné na: http://www.rulit.me/books/tam-de-pivdenread-394749-16.html [cit. 27. 12. 2016, online]

12 KOZLOVSKIJ, Vladimir: Argo russkoj gomoseksualnoj subkultury. Materialy k izučeniju. Benson: Chalidze Publications, 1986, s. 96.

13 ULJJANENKO, Oles': Tam, de pivden'. Dostupné na: http://www.rulit.me/books/tam-de-pivdenread-394749-17.html [cit. 27. 12. 2016, online] 
hned dva texty, které si nárokují titul prvního ukrajinského gay románu. Média téměř přehlédla fantasy $H a M a p c^{14} \mathrm{z}$ května roku $2015^{15}$ a pozornosti se dostalo o pár měsíců později až poněkud naivní próze Тепло його долонь debutujícího Jurije Jaremy. ${ }^{16}$

Jarema se ve svém románu nesnaží šokovat a upoutat pozornost přílišnou otevřeností. V rámci tohoto přístupu tudíž využívá cudnější popisy než někteří výše jmenovaní, což je jistě jedna z možných cest zisku na svou stranu konzervativnějších čtenářů mimo okruh konzumentů gay literatury. V románu sledujeme především citový život hlavního hrdiny - mladíka, který se rozhodne vydat se z venkova za štěstím do velkoměsta, přičemž jeho představa štěstí je zcela totožná s partnerským vztahem, který doufá nalézt. (Nepř́liš rafinovaný příběh v mnohém připomene slavná Крылья Michaila Kuzmina.) Originálnější je Jarema v popisu ukrajinských reálií, do nichž děj vsadil a díky čemuž může kritizovat ne ideální postavení homosexuálů ve společnosti, ovšem i tomto případě je autor v románu povětšinou nekonfliktní: „- Припини, все буде гаразд! У Києві зустрінутъ відвезуть до квартири, все покажуть. А з понеділка заступлю на роботу. Усі ж ми дорослі люди!

- А я не припиню, поки не знатиму на сто відсотків, шо в тебе все гаразд!

- Ромия правий, - втрутився Сашко. - I ще, друже.. Не дуже там про себе всім кажи. Хай навіть столиия, а все ж чужий край, тож обережність не завадить.

- Ну все, хлопиі! Переконали! Я все зрозумів! Буду поводитисъ, як партизан: тихо, спокійно, підпільно." 17

Rusky píše básník Vitalij Juchymenko, který přináší do gay literatury poněkud bojovnější tón. Namísto Jaremova umírněného zobrazování některých společenských nešvarů, se Juchymenko snaží charakterizovat pozici určenou homosexuálům s ironií. Do svých textů s oblibou zasazuje autobiografické rysy, lépe řečeno, píše takovým způsobem, aby ve čtenáři vyvolal dojem autobiografičnosti. Důležitou roli v Juchymenkově pozici hraje vědomí vlastní výlučnosti, pozice mimo hlavní proud: „как советские граждане становились / гомосексуалистами. / Там было и про меня: / выходеи из многодетной семви, воспитывался матерью, / рос без отиа, среди сестёр, тёть и бабушек, / играл в кукль, дружил с девочками, / отличался гибкостью, был раним и впечатлителен, / носил длинные волосы, примерял мамины вещи, / чувствовал себл другим - жизнь пошла под откос. / Я вдруг ясно осознал, что смотрю на мальчиков / не потому, что хочу бытъ, как и они, / сильным, смельм и хорошо сложенным, / а потому, что к ним, сильным, смелым и хорошо сложенным, / хочу забраться в штаны. / И это было ужасно, это было отвратительно. / [...] / Так я стал извращенцем, / а подобным в Эдемском саду не место, / и даже - в обществе нормальных людей. / Хотя с ними и самими оказалось не всё в порядке."18

14 Micto news. Novosti Dnepra: Dneprjanin napisal roman o gejach na Marse. Dostupné na: http://misto. news/news_feed/dnepryanin-napisal-roman-o-geyah-na-marse-13253.html [cit. 30. 12. 2016, online]

15 Lulu: Na Mars by Rayan Riener. Dostupné na: http://www.lulu.com/ca/en/shop/rayan-riener/na-mars/ paperback/product-22163085.html [cit. 30. 12. 2016, online]

16 Vesti: V Ukraine napisan pervyj romn pro gejev. Dostupné na: http://vesti-ukr.com/kultura/116433-vukraine-napisan-pervyj-roman-pro-geev [cit. 30. 12. 2016, online]

17 JAREMA, Jurij: Teplo joho dolon‘. Lviv: Vydavnyctvo Anetty Antonenko, 2015, s. 36.

18 JUCHYMENKO, Vitalij: Ja uznal, čto ja pidor. Dostupné na: http://sferaua.com/index.php/inshi/234-vitalii-yukhymenko-poeziia [cit. 30. 12. 2016, online] 
Juchymenko sám sebe vyčleňuje z většiny, pokouší se nezapadnout do davu, jenž zesměšňuje. Autor tak dává nahlédnout do pocitů a zážitků homosexuála, avšak i to skrze využití nejrůzněǰších stereotypů zpochybňuje jako triviální. Díky takovému přístupu se Juchymenkovi daří vystavět situace ve své podstatě realističtější, než by se kdy mohlo podařit patetickému Juriji Jaremovi: „Когда я жил в студенческом общежитии, / парни пробирались ко мне, карабкаясь по балконам, / через окно кухни $[\ldots]$ / [...] / Заблаговременно отперев окно, / я стоял [...] / как маленькая принщесса, / [...] / Но, отпирая окно, маленькая принщесса знала, / что нет преград для смелого рымаря, / человека-паука, агента 007 и супермена, / и он проникнет к ней в горнииу, / чтобы сорвать почелуй и мимоходом спасти её. / Это была необъиная приниесса."19

Oles Barlih je v rámci ukrajinské gay literatury těžko opominutelný, nebot je jedním z editorů antologie současné LGBT literatury 120 сторінок содому, v níž se podařilo propojit v jedné knize 30 autorů z celého světa. ${ }^{20}$ Nejen v rámci předmluvy a doslovu se v antologii setkáváme s odkazováním se na začlenění ukrajinské homoeroticky laděné tvorby do velké skupiny západní queer literatury a queer subkultury.

Barlih se oproti výše zmíněným autorům již nesnaží za každou cenu téma pojmenovat. Přestože píše o tom samém, jeho texty už nesledují výchovné cíle, nesnaží se sebe a sobě podobné před čtenářem nijak obhajovat nebo $\mathrm{s}$ ním polemizovat. $\mathrm{V}$ krátké próze Ненавиджу Barlih ani nemá potřebu přímo v textu sdělovat, že jeho tvorba přináleží do proudu gay literatury, protože i náznaky mluví za sebe. K tomuto účelu autor klasicky využívá stereotypy, s nimiž však pracuje nápaditěji, než jeho kolegové - Barlihův hrdina (opět navozující dojem autobiografických rysů) přemýšlí o tom, která barva mu sluší, v čem vypadá bledý, hubený, mluví o odstínech barev a oblečení tak, jak by o situaci „pravý“ muž neuvažoval: „Теперь синий ивет мне чаще “к лииу”. Раньще с ним был полный кошмар - когда я надевал что-нибудь синее, мое лиио становилось бледным, набрякиим, под глазами проявлялись темные круги. И сам я казался толще. Потом синий немного утихомирился. То ли привык ко мне, то ли просто устал от моих настойчивых попыток приручить его. Я делал это осторожно. Надевал синий сначала понемногу - какую-нибудь шведку с тоненькой темно-небесной окантовкой. ${ }^{\text {"21 }}$

Již při výběru takto skromného vzorku textů, s nimiž jsme se setkali výše, je patrné, že téma se od devadesátých let postupně stává sice menšinovou, ale organickou součástí ukrajinské literatury. Autoři se někdy úspěšněji, někdy méně zdařile snaží téma v místních podmínkách dále rozvíjet. Zdá se, že lépe se s tímto potýkají osvědčení autoři (Zabužko, Uljanenko), pro něž má téma potenciál napomoci k vytvoření barevnějšího obrazu čtenářům předkládaných přiběhů. Román Jurije Jaremy, přináší sice zajímavé momenty, avšak spíše ze společenských než estetických důvodů. Jarema se tak potýká s kýčem, jemuž se Juchymenko často vyhýbá. Tvorba Olese Barliha je pak již nadstavbou nad oběma předchozími autory, jelikož jeho texty jak s ironií, tak s momenty sklouzáva-

19 JUCHYMENKO, Vitalij: Komnata 233. Dostupné na: http://sferaua.com/index.php/inshi/234-vitaliiyukhymenko-poeziia [cit. 30. 12. 2016, online]

20 ŠUVALOVA, Irina - POZDNJAKOVA, Albina - BARLIH, Oles' (eds.): 120 storinok sodomu. Sučasna svitova lesbi/gej/bi literatura. Kvir-antolohija. Kyjiv: Krytyka, 2009.

21 BARLIH, Oles': Nenavydžu. Dostupné na: http://web.znu.edu.ua/99/k34.php [cit. 30. 12. 2016, online] 
jícími ke kýčovitosti pracuje po vzoru kvalitnější queer literatury. Barlih neřeší postavení homosexuála ve společnosti, nesoustředí se na obhajobu „gay“ vidění světa, téma homosexuality posouvá o úroveň výše a prokazuje, že má nad tématem nadhled. Primárně tak homosexualitu v tomto případě nenalézáme v popisovaném ději a postavách, jako spíše v textu samotném, ve výběru jazykových prostředků.

Při zpracování tématu homosexuality se autoři nemohou vyhnout stereotypům a určitým víceméně reálným obecně rozšířreným představám, které v této oblasti panují, at̉ už je někteří sami dále rozvíjejí a rozpracovávají (Andruchovyč, Jarema), nebo je představují s nadhledem a ironií (Juchymenko, Barlih), či je originálně narušují (Uljanenko).

Oksana Zabužko je považována za jeden z příkladů toho, jak si ukrajinská literatura progresivně osvojuje v ženské problematice orientaci na evropské a americké výdobytky feminismu nejen v oblasti tematické a v postavení literatury a autorky ve společnosti, ale i v literární teorii. ${ }^{22} \mathrm{~V}$ tomto světle má její udělení pozornosti lesbickému tématu o něco jiné ladění nežli zájem o problematiku gayů u ostatních zmiňovaných literátů.

Nelze nechat bez povšimnutí, že v případě tématu homosexuality bychom mohli očekávat, že vzorem pro začínající autory bude západní literatura, avšak zvláště v gay literatuře je situace poněkud jiná. Pro některé tvưrce je toto téma totiž spjato s ruskými autory a s ruskou literaturou. V jejich tvorbě nacházíme odkazy na ruské klasiky Michaila Kuzmina a Jevgenije Charitonova, ale též na současné mladé autory (Vasilij Čepelev a další). Lze se tedy zamýšlet nad tím, nakolik významnou roli hraje ve formování ukrajinské gay literatury západní a nakolik ruská tradice (přičemž ruská gay literatura je souhrnem vlivů domácích a západních).

Samostatnou kapitolou by byla analýza ohlasů kritiky, jak na jednotlivá zmíněná díla, tak též na zkoumané téma v širším kontextu, avšak to není ani cílem, ani v možnostech tohoto příspěvku. V našem článku též nereflektujeme změny ve vnímání tématu jednotlivými autory způsobené událostmi roku 2013 a následujícími. Lze předpokládat, že dřívější představy některých z nich ustoupily do pozadí a nové priority odsunuly téma homosexuality na vedlejší kolej, což by však zasluhovalo podrobnější analýzu, nebot ta by měla potenciál odpovídat i na obecnější otázky dalšího směřování nejnovější ukrajinské literatury.

\section{Primární literatura}

ANDRUCHOVYČ, Jurij: Moskoviada. Dostupné na: http://www.ukrcenter.com/Лiтература/ Юрій-Андрухович/24810-1/Московіада [cit. 27. 12. 2016, online]

BARLIH, Oles': Nenazydžu. Dostupné na: http://web.znu.edu.ua/99/k34.php [cit. 30. 12. 2016, online]

JAREMA, Jurij: Teplo joho dolon'. Lviv: Vydavnyctvo Anetty Antonenko, 2015.

JUCHYMENKO, Vitalij: Komnata 233. Dostupné na: http://sferaua.com/index.php/inshi/234vitalii-yukhymenko-poeziia [cit. 30. 12. 2016, online]

22 REVAKOVYČ, Marija: Gender, heohrafija, mova: u pošukach identyčnosti v sučasnij ukrajins’kij literaturi. L’viv - Kyjiv: Centr humanitarnych doslidžen' - Smoloskyp, 2012, s. 33. 
JUCHYMENKO, Vitalij: Ja uznal, čto ja pidor. Dostupné na: http://sferaua.com/index.php/ inshi/234-vitalii-yukhymenko-poeziia [cit. 30. 12. 2016, online]

ULJANENKO, Oles': Tam, de pivden'. Dostupné na: http://www.rulit.me/books/tam-de-pivdenread-394749-1.html [cit. 27. 12. 2016, online]

ZABUŽKO, Oksana: Sestro, sestro. Kijiv: Fakt, 2004.

\section{Sekundární literatura}

CHLAŇOVÁ, Tereza a kol.: Putováni současnou ukrajinskou literárni krajinou. Prozaická tvorba představitelů tzv. „stanislavského fenoménu“. Červený Kostelec: Pavel Mervart, 2010.

CHOFMAN, Tatjana: Literaturnyje etnografii Ukrainy: Proza posle 1991 goda. Sankt-Peterburg: Aletejja, 2016.

KOZLOVSKIJ, Vladimir: Argo russkoj gomoseksualnoj subkultury. Materialy k izučeniju. Benson: Chalidze Publications, 1986.

MERZOVÁ, Radana: Současná ukrajinská literatura. In: PECHAL, Zdeněk a kol.: Současná ruská, polská a ukrajinská literatura. Olomouc: Univerzita Palackého v Olomouci, 2013.

REVAKOVYČ, Marija: Gender, heohrafija, mova: u pošukach identyčnosti v sučasnij ukrajins'kij literaturi. Lviv, Kyjiv: Centr humanitarnych doslidžen'; Smoloskyp, 2012.

STEPULA, Nadija: U znjatomu na plivku dni. Kyjiv: Ukrajins'kyj priorytet, 2012.

ŠUVALOVA, Irina - POZDNJAKOVA, Al'bina - BARLIH, Oles' (eds.): 120 storinok sodomu. Sučasna svitova lesbi/gej/bi literatura. Kvir-antolohija. Kyjiv: Krytyka, 2009.

Vesti: V Ukraine napisan pervyj roman pro gejev. Dostupné na: http://vesti-ukr.com/kultura/116433-v-ukraine-napisan-pervyj-roman-pro-geev [cit. 30. 12. 2016, online]

Micro news. Novosti Dnepra: Dneprjanin napisal roman o gejach na Marse. Dostupné na: http:// misto.news/news_feed/dnepryanin-napisal-roman-o-geyah-na-marse-13253.html [cit. 30. 12. 2016, online]

Lulu: Na Mars by Rayan Riener. Dostupné na: http://www.lulu.com/ca/en/shop/rayan-riener/ na-mars/paperback/product-22163085.html [cit. 30. 12. 2016, online]

\section{Mgr. Jaroslav Sommer}

Katedra ruského jazyka a literatury

Pedagogická fakulta, Univerzita Hradec Králové

Rokitanského 62, 50003 Hradec Králové, Česká republika

jaroslav.sommer@uhk.cz 